\title{
Banjarese Culture Perspective In Hygiene Habit Of Female Teenage External Reproductive Organ In Banjarmasin
}

Dini Rahmayani ${ }^{1 *}$

${ }^{1}$ Sari Mulia Institute of Health Science, Banjarmasin, Indonesia

*dinirahmayani@yahoo.com

Umi Hanik $^{1}$

${ }^{1}$ Sari Mulia Institute of Health Science, Banjarmasin, Indonesia umi_hanik_f04@yahoo.co.id

Rifa'atul Mahmudah ${ }^{1}$

${ }^{1}$ Sari Mulia Institute of Health Science, Banjarmasin, Indonesia rivaayoenani@gmail.com

Wika Rispudyani ${ }^{2}$

${ }^{2}$ Ulin General Hospital, Banjarmasin

wika_rosefa@yahoo.com

\begin{abstract}
Objective: to analyse banjarese culture in hygiene habit of female teenage external reproductive organ, analysing banjarese culture myth ini reproductive organ care and analysing family contribution in reproductive organ care.

Method: qualitative approach by deep interview to visualized in detail about application banjarese culture in teenage external reproductive organ. Research respondent are female teenager and parents in MTsN Banjar Selatan 2 Banjarmasin. Data was analysed by Miles and Huberman.

Result: Teenage mostly look for information resource from their friends, media, and information from their parents based on experience and culture but it is not exactly true, its might push bad hygiene habit of female teenage external reproductive organ.

Conclusion: Banjarese culture in female teenege external reproductive organ are based on the family that is nearest environment for them and their friend. The use of speces and leaves also used female teenage as the ingredients of external reproductive organs.
\end{abstract}

Keywords: banjarese culture, external reproductive organ, family role, and hygiene habit

\section{INTRODUCTION}

Adolescence is a period of the cycle of human development, the transition between the childhood to adulthood suggested to know the details of reproduction health, especially about the basic thing is the reproductive organs. Everyone must do as much as possible to care for the reproductive organs because it can bring in various diseases [1].
The teenage girl aged 13-15 years from three schools, obtained an average result is not good in performing hygiene care of the reproductive organs during menstruation, only $60 \%$ of teenage girl know that menstruation is a physiological process [2]. The knowledge gained by teenage girl based on several sources such as from parents who convey about the habit that is a culture to treat reproductive organ hygiene. 
The cultures that occur in reproductive care are passed down from generation to generation in accordance with the beliefs that the family believes are passed on in the form of day-to-day behaviors and habits to children and grandchildren. The problem with the implementation of culture in reproductive health care is not that all cultures in reproductive care make a positive contribution but instead.

Families as two or more persons are united by the bonds of togetherness and emotional bonding and identify themselves as part of the family [3]. The family is also the main actor closest to the teenager in carrying out the culture, because the family is the closest environment to teenage girl, therefore the cultural expectations that are inherited in the care of the reproductive organs should be ensured to be true and have a positive impact.

In Banjarmasin most of the inhabitants still live in riparian areas and have a diversity of cultures that can affect access to health, so that they get the latest information on reproductive health including on the hygiene care of external reproductive organs is very limited. From the data of Community Health Centers (CHC) in Banjarmasin, urinary tract infections (UTI) in the work area of CHC South Banjar in 2008, 72 cases increased to 100 cases up to November 2009. Based on preliminary study obtained data has never been any extension about hygiene treatment of external reproductive organs. While the average students say parents never give knowledge of hygiene maintenance organs of reproduction or genitalia and complain of itching and washing with soap.

Based on the background of the problem then in this study want to know the general trend about culture in hygiene behavior of external reproductive organs of teenage girl in Banjarmasin, South Kalimantan, especially in Madrasah Tsanawiyah Negeri (MTsN) two Banjarmasin.

\section{RESEARCH METHODS}

The research was conducted with qualitative approach with the selection of informants determined based on information obtained as 12 people, consisting of students, parents, counseling teachers and school health unit teachers and CHC staff. Place of Research in Madrasah Tsanawiyah Negeri (MTsN) South Banjar two Banjarmasin. The study was conducted in 2010. The data analysis with Miles and Huberman model [4].

\section{RESULT}

The results of interviews with teenage girl respondents, and their parents, revealed that in maintaining hygiene of reproductive organs is important, they consider the purpose of maintaining the hygiene of reproductive organs for disease prevention, itching, and just 
know to maintain health. As expressed by the following respondents:

"I think it's important to be maintained, so as not itch, .. and not to be exposed to disease genitals "(Informant teenage girl 1).

“..,yes .., important .., ehm .. because if it's not maintained, health can be disrupted .. "(Informant teenage girl 3).

Basically teenage girls should know how it should be in the hygiene of external reproductive organs, how the actions taken when they begin to feel a complaint on the area of external reproductive organs. But in its daily implementation can be different as revealed as follows:

"Usually I wash it with betel soap, .. just 1 week 3 times, .. I also wear if I got menstruation, sometimes mom bought it for me, told to wear, but not up to it, usually wash direction from the anus fore "(Informant teenage girl 3).

"Sometimes if Ifeel itched, I carded it, if it still, I did again,, yes ,, carded constantly, .. until it's not itch again, and stop carded after it sores, .. do not get wound, use betel soap also for wash it or it can use ordinary soap, sometimes often also feel moist, but just left alone "(Informant teenage girl 3).
Hygiene behavior of external reproductive organs in teenage girl is also done by using various ingredients from herbs and foliage taught by the their parents, as revealed as follows:

"Yes .., use water .., tap water, usually from front to back, my sister told me to use betel soap, even itch, if menstruation I usually use sanitary napkin, if there's so many blood.., just changed it, washed first before throw it, then change again with a new one, ... yes approximately 2-3 times a day "(Informant teenage girl 2).

The opinion of some parents of adolescent girls in indepth interview obtained the result that women seem to use the source of local or traditional materials for the treatment of external reproductive organs, as expressed as follows:

"Usually use betel soap, if itching, the betel leaf soaked with hot water, or watered, knead betel leaves, or can also be boiled, after boiling until the water is reduced mixed it with cold water, then splashed, .. if menstruation, we usually also drink turmeric, let the body guns smell away, if menstruation betel leaf in boiled continue in strain, I also can ordered her to drink brown sugar water and tamarind, let the blood of her menstruation sick out .., said people used to be like that "(informant teenage mother 4). 
"If in Banjarmasin, .. starting from the baby .. the genital flushed with lemon juice, .. after that given again with lime juice, "(informant teacher 2).

"Also at the first menstrual period, her parents celebrate it, such as thanksgiving, and there is usually the first blood in the greeting (taken) with a white cloth, perhaps because the parents' pleasures of their daughter have grown up, so the celebration is held "(informant teacher 1 ).

Some differences of opinion, sometimes parents have felt enough with their role as her parents in delivering about the hygiene of external reproductive organs to their daughter, as revealed below:

“..It's enough to teach, .. yes, .. there may be less, because the problem is a lot "(informant teenage mother 2).

“..It's still not, and I have limited knowledge, so far I know about it from generation to generation only, because if from the magazine, I don't really read, so I tell her which I know"(informant teenage mother 3).

In carrying out the role of parents to the hygiene of external reproductive organs in their teenage daughter found several obstacles, but there are also feel there is no obstacle as follows:
“...Hmm .. I feel awkward, embarrassed sometimes to talk about it, if she feel embarrassed "(informant teenage mother 1).

“Just smoothly, ... it just cleaned it up, I also know from my mom (grandmother), .. actually it is my duty to tell my child, but I am limited in knowledge, and more rarely see the child,.. so how "(informant teenage mother 3).

The results of interviews with teenage girl and parents, teachers, and health personnel, there's so many factors that affect the hygiene of external female reproductive organs. The teenage girl reveal that the most convenient source of information they think about the hygiene of female reproductive organs is from television, parents and peers. This is revealed by the following informants: “..from the parents, .. hmmm slightly covered, not shy to tell, not afraid to be told with others "(informant teenage girl1).

“..most comfortable with friends, if parents we just embarrassed, I'm okay to tell my friends, if from magazines I rarely read "(informant teenage girl 2).

For teenage girls parents from interviews said that parents who become the best source of information for their teenage daughter. 


\section{DISCUSSION}

The hygiene behavior of external reproductive organs in teenage girl is based on various sources of information, one of which is first obtained from parents. Parents tend to get the source of information based on their own experiences and from the parents' mother, it is relayed back to their teenage daughter and hereditary, although the parents are not yet aware of the truth or accuracy of information regarding the hygiene of the external reproductive organs they convey to their teenage daughter. In general, teenage girl and their parents share the same view of the importance of hygiene of external reproductive organs. The motivation of women to treat external reproductive organs is quite different, but generally can be described for purposes of hygiene, health, and well-being, or sexuality [5].

Teenage girl parents often advise their children to use traditional herbs and vaginal cleansing products sell in the market, although sometimes teenage themselves feel uncomfortable using the product. Traditional herbs are believed to improve the health and well-being of the external reproductive organs of their teenage daughter, such as plants or leaves, among others: turmeric, betel, brown sugar, tamarind and nifis orange, this is done from generation to generation. The results are consistent with previous research with the result that women at all study sites appear to use local sources of reproductive organ administration for vaginal area [5]. The products range from the traditional, which includes: plants, leaves, bark, fruit, feathers, and food for commercially distributed manufacturing industries such as tonics, soaps, and vaginal creams. For example in Indonesia, women use betel leaf juice (betel) for therapy when menstrual cramps and clean the vaginal area. In accordance with the results obtained are similar to what happened to the present in the community in Banjarmasin based on the results of this study.

The role of parents they get in terms of providing information about the hygiene of external reproductive organs is still very poor, and very rarely provide information relating to it, parents only provide limited information, whereas teenage girl feel that it is more comfortable to get from parents they are direct because they are related to their own privacy. The role of a good parent will result in good hygiene behavior of the external teenage girls reproductive organs. The results of this study support the research that has been done with the results of research that the knowledge of teenage girl in terms of hygiene behavior of external reproductive organs is very bad or low [2]. In the research is expected parents as family members can run its role to be able to provide information about hygiene behavior of external reproductive organs other than teachers and other health workers. Talking 
about the role of the family can not be separated from the function of the family itself, the family function is important for all family members, both the family life itself is to give care, compassion, familiarity, and tenderness [6].

Another study found results that teenage girl get a source of information about the hygiene care of reproductive organs from friends, which is expected in this study family as the nearest environment teens can provide the right information [7].

Parents are a very important part of efforts to improve teenage girls reproductive health status, their thoughts, views, support and involvement will greatly determine the behavior of teenage themselves in terms of reproductive health. The information from their parents about the hygiene of external reproductive organs is very influential on hygiene behavior of external reproductive organs of teenage girl themselves. Thus the need for a good family role on hygiene behavior of external reproductive organs of teenage girl because the family as the closest to the teenage girl themselves. Parents as family members are the first parties responsible for providing information on reproductive health for teenagers [8].

Parents of teenage girl convey information at the time of menstruation is limited to knowledge and personal experience only, which the parents obtained from the mother (grandmother teenage daughter) who then delivered back to the teenage girl. The same results obtained from some studies that parents are not maximally provide the information because there are several factors that are knowledge of the parents themselves, and the existence of cultural factors are still ashamed to discuss reproductive health issues. This information should be delivered early before the teenage daughter has menstruation [9]. The results are also consistent with some studies that recommend that teenage girl get a source of information about the hygiene care of reproductive organs from their friends, which is expected in this study family as the nearest environment of the teenagers who can provide the right information, teenage girl stated that they desperately need more information Furthermore, since most children get first information about the hygiene behavior of external reproductive organs including girls about menstruation is from mother, sister, and friends $[7,10,11,12]$. A good family role can improve adolescent reproductive health status, where the family is the production of health itself.

\section{CONCLUSION}

The use of traditional herbs in hygiene behavior of external reproductive organs is derived from plants and leaves that are believed to improve hygiene, health, and wellbeing, or sexuality and the lack of family roles 
on hygiene behavior of external reproductive organs in teenage girl.

\section{REFERENCES}

[1] Walsh, M. Sexual Health in Practice: The Female Reproductive System. USA: Royal College of Nursing. 2007.

[2] Adhikari, P., Kadel, B., Dhungel, S.I. \& Veerammal, S. Knowledge and practice regarding menstrual hygiene in rural adolescent girls of Nepal. PMD, 5(3):382386, 2007.

[3] Friedman, M.M. Keperawatan Keluarga Teori dan Praktek, edisi 3. Jakarta: EGC.

[4] Miles, M.B. dan Huberman, A.M. Qualitative data analisis: Analisis data kualitatif. Alih bahasa Tjetjep Rohendi Rohidi. Jakarta: UI-Press. 2007.

[5] Hilber, A.M., Hull, H.T., Whyte, E.P., Bagnol, B., Smit, J., Wacharasin, C. \& Widyantoro, N. A cross cultural study of vaginal practices and sexuality: implications for sexual health. Soc Sci Med, 70(3):1-9. 2009.

[6] Tungsuwannawong, S. The relationships between family functioning and selfesteem in early adolescents in Kanchanaburi province. Thesis, Mahidols University, 2007.

[7] Dhingra, R., Kumar, A. \& Lour, M. Knowledge and practice related to menstruation among Tribal (Gujjar) adolescent girls. Ethno-Med, 3(1):43-48. 2009.

[8] Steinberg, L. \& Duncan, P. Increasing the capacity of parent, famillies, and adults living with adolescent to improve adolescent health outcomes. $J$ Adolesc Health, 31(15):261-265.

[9] Ahmed, R \& Yesmin, K. Menstrual hygiene: Breathing the silence. Higiene Promotion, 283-287, 2005.

[10] Hadi, A., Gilany, E., Badawi, K. \& Fedaway, E. (2005) Menstrual hygiene among adolescent schoolgirls in Mansoura, Egypt. Reprod Health Matters, 13(26):147-152.
[11] Shadana, J \& Achala, S. Awareness about reproduction and adolescent changes among school girls of different socioeconomic status. J Obstet Gynecol India, 56(4):324-328, 2006.

[12] Dasgupta, A. \& Sarkar, M. Menstrual hygiene: How hygiene is the adolescent girl. Indian Journal of Community Medicine, 33:77-80, 2008. 